\title{
AN INCONSISTENCY IN CRAIG'S DEFENCE OF THE MORAL ARGUMENT
}

\author{
ERIK J. WIELENBERG
}

DePauw University

\begin{abstract}
I argue that William Craig's defence of the moral argument is internally inconsistent. In the course of defending the moral argument, Craig criticizes non-theistic moral realism on the grounds that it posits the existence of certain logically necessary connections but fails to provide an adequate account of why such connections hold. Another component of Craig's defence of the moral argument is an endorsement of a particular version of the divine command theory (DCT). Craig's version of DCT posits certain logically necessary connections but Craig fails to provide an adequate account of why these connections hold. Thus, Craig's critique of non-theistic moral realism is at odds with his DCT. Since the critique and DCT are both essential elements of his defence of the moral argument, that defence is internally inconsistent.
\end{abstract}

\section{INTRODUCTION}

In a variety of publications and debates, William Craig has defended a moral argument for God's existence. Craig's defence of the argument has recently been criticized by Wielenberg (2009) and Morriston (2012). Building on these criticisms, I argue here that Craig's defence of the moral argument is internally inconsistent. In the course of defending the moral argument, Craig criticizes non-theistic moral realism. One of his central criticisms of that view is that it posits the existence of certain logically necessary (in the broad sense; see Plantinga 1974: 44-5) connections but fails to provide an adequate account of why such connections hold. Craig claims that this is unacceptable. Another component of Craig's defence of the moral argument is an endorsement of a particular version of the divine command theory (DCT). Craig's 
version of DCT posits certain logically necessary connections but Craig fails to provide an adequate account of why these connections hold. Thus, Craig's critique of non-theistic moral realism is at odds with his DCT. Since the critique and DCT are both essential elements of his defence of the moral argument, that defence is internally inconsistent.

\section{CRAIG'S MORAL ARGUMENT}

At the heart of Craig's moral argument is the contention that objective morality has a sound foundation if and only if God exists (Garcia and King 2009: 30). A moral claim is objectively true just in case it is true and its truth is independent of human mental states in a certain way. Craig explains:

[T]o say, for example, that the Holocaust was objectively wrong is to say that it was wrong even though the Nazis who carried it out thought that it was right and that it would still have been wrong even if the Nazis had won World War II and succeeded in exterminating or brainwashing everyone who disagreed with them. (Craig and Sinnott-Armstrong 2004: 17)

Assuming that there are objective moral truths just in case objective morality has a sound foundation, it follows that there are objective moral truths just in case God exists. From the additional premise that there are some objective ethical truths (which Craig takes to be obviously true; see Craig and Sinnott-Armstrong 2004: 21), it follows that God exists.

\section{CRAIG'S VERSION OF DCT}

To support his contention that God provides a sound foundation for objective morality, Craig appeals to a version of DCT according to which (i) goodness $=$ resemblance to the necessarily existing divine nature and (ii) moral obligation = being commanded by God (Garcia and King 2009: 30, 168-73; this type of view is developed at great length in Adams 1999). Critics of Craig's moral argument often appeal to the so-called 'Euthyphro problem' in an effort to refute the claim that God provides a sound foundation for objective morality (see e.g. Craig and SinnottArmstrong 2004: 350-6; Garcia and King 2009: 70-2, 108-9). There are a number of distinct objections that have come to be associated with the label 'the Euthyphro problem'. Among these is the objection that DCT implies that any action, no matter how horrendous, could be morally 
obligatory. The thought is that God, being omnipotent, could command any act whatsoever. Since, according to DCT, for an act to be obligatory just is for it to be commanded by God, it allegedly follows that any act is at least possibly morally obligatory. The objector claims that this implication is implausible and hence DCT itself must be flawed; call this objection 'the arbitrariness problem' (the classic source of this particular worry is Cudworth 1996 [1731]: 14).

Craig is well aware of this objection; he notes that his version of DCT 'was formulated precisely so as to be immune' to this objection (Garcia and King 2009: 172). The foundation of Craig's answer to the arbitrariness problem is the claim that at least some of God's commands are 'necessary expressions' of His nature and hence are 'logically necessary' (Garcia and King 2009: 173); call such commands 'N-commands.' Suppose, for example, that the command not to rape is an N-command. What this means is that the fact that the divine nature exists entails that God issues a command not to rape. Given the assumption that to be morally obligatory $=$ to be commanded by God (the second component of Craig's version of DCT), it follows that the existence of the divine nature entails that there exists a moral obligation not to rape. Craig also maintains that the divine nature exists necessarily (Garcia and King 2009: 169-70); given this, it is also necessarily true that we are morally obligated not to rape. So, Craig's answer to the arbitrariness worry is that DCT does not imply that every action is possibly morally obligatory; the divine nature places necessary constraints on which commands God could issue, thereby placing necessary constraints on which actions could be morally obligatory. Thus, Craig's version of DCT entails:

P1: There are some divine commands, $\mathrm{C}_{1} \ldots \mathrm{C}_{\mathrm{n}}$, such that the existence of the divine nature entails the issuing of $\mathrm{C}_{1} \ldots \mathrm{C}_{\mathrm{n}}$.

\section{CRAIG'S SHOPPING LIST OBJECTION TO NON-THEISTIC MORAL REALISM}

Non-theistic moral realism is the view that there are some objective moral truths that are not somehow grounded in God. To the extent that this view is plausible, Craig's contention that objective morality has

${ }^{1}$ It is not clear whether Craig also means to advance the stronger claim that all divine commands are $\mathrm{N}$-commands. For worries about this stronger claim, see Murphy (2002: 22-4), and Baggett and Walls (2011: 119-20). 
a sound foundation only if God exists is undermined. Thus, refuting non-theistic moral realism is an important component of Craig's defence of his moral argument.

Craig often characterizes non-theistic moral realism as a 'shopping list approach', by which he means (at least in part) that it entails the existence of ungrounded objective moral truths. Wielenberg argues that "both parties to the debate [Craig and non-theistic moral realists] are stuck with a "shopping list" approach; the only difference between them is the content of their respective lists' (2009: 38-9). Similarly, Morriston claims that ' $[\mathrm{n}] \mathrm{o}$ matter what story you tell about the ontological ground of moral value, you must at some point come to your own full stop' (2012: 29). ${ }^{2}$ Craig sometimes concedes this point. For example, commenting on his and Sinnott-Armstrong's different explanations for the wrongness of rape, Craig observes that 'the difference between the theist and Sinnott-Armstrong is not that one has an explanatory ultimate and the other does not. It is rather that the theist has a different explanatory ultimate' (Garcia and King 2009: 173).

However, a closer look at Craig's 'shopping list' worry suggests that it is, at bottom, a worry about unexplained logically necessary connections. Craig at one point notes that the non-theist moral realist might hold 'that moral properties supervene necessarily on certain natural states' (Garcia and King 2009: 179). In response to this suggestion, he asserts that we have no reason to think 'given a naturalistic worldview [that] there are any moral properties or that they supervene on natural states' (Garcia and King 2009: 180). In the next paragraph Craig introduces the familiar shopping list objection:

If our approach to metaethical theory is to be serious metaphysics rather than just a 'shopping list' approach, whereby one simply helps oneself to the supervenient moral properties ... needed to do the job, then some sort of explanation is required for why moral properties supervene on certain natural states. (Garcia and King 2009: 180, emphasis added)

Here, Craig seems to assert that any approach that posits supervenience relations without explaining them is in some way or another inadequate (see Morriston 2012: 31). Supervenience is a purely logical relation. One set of properties B supervenes upon another set of properties A just in case any pair of logically possible worlds that are identical with respect

${ }^{2}$ For an interesting argument for the inadequacy of Craig's favourite stopping point a good God - see Koons (2012). 
to the properties in A are also identical with respect to the properties in B. ${ }^{3}$ Since supervenience is, at its core, a matter of the obtaining of various logically necessary connections, Craig's complaint about supervenience appears to be a complaint about the positing of unexplained logically necessary connections. In the quoted passage above, Craig speaks specifically of supervenience relations between natural and moral states and properties. But it is hard to imagine a plausible justification for the view that while positing unexplained logically necessary connections between natural and moral properties is unacceptable, positing unexplained logically necessary connections between other things is acceptable. At any rate, Craig nowhere offers any justification for such a view. So the most plausible reading of this and similar passages suggests that the central target of Craig's complaint is the positing of logically necessary connections which are then left unexplained. If this is right, then Craig's shopping list objection to non-theistic moral realism employs the following principle:

P2: Any approach to metaethics that posits logically necessary connections without adequately explaining why such connections hold is unacceptable

\section{THE INCONSISTENCY IN CRAIG'S DEFENCE}

Consider some N-command. Craig at one point offers the following as an 'explanatory ultimate: God commands us to love and not to harm one another' (Garcia and King 2009: 173). Thus, this command is a likely candidate for an N-command. As noted above, Craig's DCT implies that $\mathrm{N}$-commands are entailed by God's nature; this is P1. However, as I argue below, Craig does not provide an adequate explanation for the existence of such necessary connections. If this is correct, then P2 implies that Craig's DCT is inadequate.

Craig has relatively little to say about why any particular N-command might be entailed by God's nature; typically, he is content to claim that 'God's moral nature is expressed in relation to us in the form of divine

\footnotetext{
${ }^{3}$ Many varieties of supervenience have been distinguished (see McLaughlin and Bennett: 2011); the definition of supervenience given here is global, logical (again, in the broad sense) supervenience. This is the most relevant type of supervenience because this is the sort of supervenience that non-theistic moral realists typically maintain holds between natural and moral properties.
} 
commands ... these commands flow necessarily from his moral nature' (Moreland and Craig 2003: 491, emphasis added). Such remarks tell us little about how or why any particular N-command is entailed by the divine nature. However, he does say this: '[T]he theist can agree that God forbids rape because it is bad.' (Garcia and King 2009: 173) But this fails to explain why God's nature entails that God forbids rape. Craig emphasizes the distinction between moral goods and moral obligations, offering this example:

It is good that I become a wealthy philanthropist and support worthy causes throughout the globe; it is also good that I forgo the pursuit of wealth to become a medical missionary to Chad. But obviously I cannot do both, since they are mutually exclusive. I am not, therefore, morally obligated to do both, though both are good. Goods, then, do not imply moral obligations. (Garcia and King 2009: 172)

Just as it is possible to face a situation in which one cannot avoid failing to perform an act that it would be good to perform, it is also possible to face a situation in which one cannot avoid performing some evil act or other. In such cases, performing an evil act is morally permissible (see Adams 1999: 283). So, just as goods do not imply moral obligations, evils do not imply moral wrongness. Since, on Craig's view, for an act to be morally obligatory is for it to be commanded by God and for an act to be morally wrong is for it to be forbidden by God, it follows that the fact that an act is good does not entail that God commands it and the fact that an act is bad does not entail that God forbids it. Therefore, the fact that rape is bad cannot fully account for the alleged necessary connection between the divine nature and God's command against rape.

Craig sometimes lists some of the character traits that he thinks God has: '[God] is by nature loving, generous, just, faithful, kind, and so forth.' (Garcia and King 2009: 30) It might be thought that such a list provides the materials for explaining the connections between the divine nature and at least some N-commands. Consider the following: because God is loving, He necessarily commands that we love one another. This claim has a certain ring of plausibility to it, but notice that it posits a logically necessary connection between being loving and issuing the command that we love one another. P2 implies that unless Craig provides an explanation for this necessary connection, his meta-ethical approach is unacceptable. To my knowledge, Craig nowhere provides such an explanation. 
It might be suggested that explanation has to come to an end somewhere; don't we eventually arrive at a fundamental necessary connection, one such that we can see that it is true even if we cannot explain how or why it is true? I am sympathetic to this reply. However, it is not a reply that is available to Craig, for P2 sets a very high bar of adequacy for meta-ethical theories: they must not posit any unexplained necessary connections. The bar is so high, in fact, that Craig's own metaethical theory falls short.

At this point, one might wonder: what would count as an adequate explanation of a logically necessary connection? From Craig's perspective, one likely answer is that one can explain a logically necessary connection between A and B if one can plausibly claim that A just is B. Recall that on Craig's view, goodness just is resemblance to God, and moral obligation just is being commanded by God. That is why Craig thinks he can adequately explain the logically necessary connections between God and goodness and between divine commands and moral obligation. It may be that Craig thinks that no corresponding strategy is available to the non-theist because there are no natural properties that could plausibly be claimed to constitute goodness and moral obligation. If Craig is right about that, then the non-theistic moral realist must posit logically necessary connections between natural properties and distinct moral properties - but since the non-theist cannot adequately explain these connections, her view runs afoul of $\mathrm{P} 2$. What Craig seems not to notice is that while his brand of DCT may avoid positing unexplained necessary connections between God and goodness and between moral obligation and divine commands, it does posit other unexplained necessary connections, thereby running afoul of P2. In this way, Craig is hoisted by his own petard.

Finally, it is worth noting an obstacle to explaining the alleged necessary connections between the divine nature and divine commands that emerges from traditional Christian theism itself. The obstacle is suggested by, for instance, the well-known declaration in Isaiah that ' $\mathrm{f}$ ] or as the heavens are higher than the earth, so are [God's] ways higher than your ways and [God's] thoughts higher than your thoughts' (Isaiah 55:9), as well as Paul's remark that God's judgments are 'unsearchable' and His ways 'inscrutable' (Romans 11:33). ${ }^{4}$ Such passages suggest a substantial gap between human and divine knowledge. Stephen Wykstra says:

\footnotetext{
${ }^{4}$ Also relevant here are Job, and Ecclesiastes 8:17.
} 
'A modest proposal might be that [God's] wisdom is to ours, roughly as an adult human's is to a one-month old infant's.' (1984: 88) One area in which our understanding of reality may be notably inferior to God's is knowledge of good and evil. Michael Bergmann suggests that 'it wouldn't be the least bit surprising if [axiological] reality far outstripped our understanding of it' (2001: 284) and that for all we know, there are lots of goods, evils, and connections between good and evil of which human beings are unaware (Bergmann 2009). This collection of ideas is the basis of the so-called 'sceptical theist' response to the evidential problem of evil. Craig appeals to sceptical theism himself in addressing the problem of evil (Craig and Sinnott-Armstrong 2004: 116-9). These ideas suggest that there is much about the divine nature that we do not know, particularly when it comes to God's moral nature. And this suggests that there is likely an insurmountable barrier to our understanding of whatever necessary connections may obtain between the divine nature and at least some divine commands. I noted earlier that Adams has provided the most developed version of Craig's brand of DCT. Adams emphasizes the transcendence of the divine nature, one of the implications of which is an inevitable limit to human beings' ability to grasp it. Here is a particularly striking expression of this view:

The Holy [ = the Good = the divine nature] is fascinating; the Holy is beautiful; the Holy is bliss; the Holy is just, the Bible claims, though we may not understand its justice ... From a human point of view, the Holy has rough edges. It screams with the hawk and laughs with the hyenas. We cannot comprehend it. ... We are not the measure of all things, and have at best a very imperfect appreciation of the full dimensions of the good. (Adams 1999: 52)

This bodes ill for the prospects of providing adequate explanations for the necessary connections between the divine nature and any putative $\mathrm{N}$-command.

\section{CONCLUSION}

If the argument of this paper is correct, then Craig faces a dilemma. To provide an adequate defence of his moral argument, Craig must defeat non-theistic moral realism. Many of Craig's criticisms of nontheistic moral realism have been ably criticized by Wielenberg (2009) and Morriston (2012). When pressed, Craig typically resorts to the 'shopping list' objection described above; this is often his final critique 
of non-theistic moral realism (see, for example, Craig and Moreland 2003: 493; Craig and Sinnott-Armstrong 2003: 171; and Garcia and King 2009: 180). However, once we see what lies at the heart of the shopping list objection, we see that this objection applies equally to Craig's favoured version of DCT. Moreover, it is precisely those aspects of Craig's version of DCT that, according to Craig, enable that view to avoid the arbitrariness problem that make it susceptible to the shopping list objection. Craig's dilemma, then, is this: to provide an adequate defence for his moral argument, Craig must both defeat non-theistic moral realism and answer the arbitrariness problem for DCT. But if I am right, he cannot accomplish both of these tasks - at least, not with the arguments and claims he has advanced so far. ${ }^{5}$

\section{BIBLIOGRAPHY}

Adams, Robert. 1999. Finite and Infinite Goods (Oxford: Oxford University Press) Baggett, David, and Jerry L. Walls. 2011. Good God: The Theistic Foundations of Morality (Oxford: Oxford University Press)

Bergmann, Michael. 2001. 'Skeptical Theism and Rowe's New Evidential Argument', Nous, 35: 278-96

Bergmann, Michael. 2009. 'Skeptical Theism and the Problem of Evil', in The Oxford Handbook of Philosophical Theology, edited by Tom Flint and Michael Rea (Oxford: Oxford University Press), pp. 374-402

Craig, William Lane. 2003. 'A Reply to Objections', in Does God Exist? The Craig-Flew Debate, edited by Stan Wallace (Burlington, Vermont: Ashgate), pp. $155-88$

Craig, William Lane, and Walter Sinnott-Armstrong. 2004. God? A Debate Between a Christian and an Atheist (Oxford: Oxford University Press)

Cudworth, Ralph. 1996 [1731]. A Treatise Concerning Eternal and Immutable Morality, edited by Sarah Hutton (Cambridge: Cambridge University Press) Garcia, Robert K., and Nathan L. King, 2009. Is Goodness without God Good Enough? (New York: Rowman \& Littlefield)

Koons, Jeremy. 2012. 'Can God's Goodness Save the Divine Command Theory from Euthyphro?', European Journal for the Philosophy of Religion, 4:1: 177-95 McLaughlin, Brian, and Karen Bennett. 2011. 'Supervenience', The Stanford Encyclopedia of Philosophy (Winter 2011 Edition), edited by Edward N. Zalta. $\mathrm{URL}=\langle$ http://plato.stanford.edu/archives/win2011/entries/supervenience/ $>$ [accessed 21/11/2012]

${ }^{5}$ The writing of this paper was made possible by a DePauw University Faculty Fellowship. 
Moreland, J. P., and William Lane Craig. 2003. Philosophical Foundations for a Christian Worldview (Downers Grove, Illinois: InterVarsity Press)

Morriston, Wes. 2012. 'God and the Ontological Foundation of Morality', Religious Studies, 48: 15-34

Murphy, Mark. 2002. 'A Trilemma for Divine Command Theory', Faith and Philosophy, 19:1(January): 22-31

Plantinga, Alvin. 1974. The Nature of Necessity (Oxford: Oxford University Press)

Wielenberg, Erik J. 2009. 'In Defense of Non-Natural, Non-Theistic Moral Realism, Faith and Philosophy, 26:1 (January): 23-41

Wykstra, Stephen. 1984. 'The Humean Obstacle to Evidential Arguments from Suffering: On Avoiding the Evils of "Appearance", International Journal for Philosophy of Religion, 16: 73-93 